\title{
Factor X Deficiency: A Rare Case of Inherited Coagulation Disorder Presenting as Hemarthrosis
}

Sinha $S^{1}$, Barik $S^{2}$

${ }^{1}$ Dr Sweta Sinha, Senior Resident, Department of Transfusion Medicine, ${ }^{2}$ Dr Sumit Barik, Specialist and designated Associate Professor ( Hematology ), Department of Pathology and Hematology. Both are affiliated with ESI Post Graduate Institute of Medical Science and Research, New Delhi. 110015, India

Address for correspondence: Dr. Sumit Barik, Email: bariksumit@yahoo.com

\begin{abstract}
Hemophilia due to factor VIII deficiency is most common inherited bleeding disorder in paediatric population. Hemarthrosis is initial manifestation in large number of patients. We are presenting a case of factor X deficiency who presented with knee hemarthrosis.
\end{abstract}

Key words: Hemarthosis, Factor X deficiency, Bleeding disorder.

\section{Introduction}

Hemarthrosis is classical presentation in Hemophilia A which is a genetic disorder of factor VIII deficiency.

However other coagulation disorders ususally do not present with hemarthrosis. Factor X deficiency is a very rare disorder of coagulation. Two patients at different places with the names of Ms.

Prower and Mr. Stuart were first to be diagnosed with factor X deficiency in the year 1956 and 1957 [1]. The incidence of severe factor $X$ deficiency is 1 in 20,00,000 [2]. It is a vitamin $\mathrm{K}$ dependent serine protease that circulates in plasma.

Plasma levels are $8-10 \mu \mathrm{g} / \mathrm{ml}$. Half-life in plasma is 34 40 hours. It plays a crucial role in the coagulation cascade. Factor $\mathrm{X}$ is activated either by factor $\mathrm{VIIa} / \mathrm{TF}$ (tissue factor) complex via extrinsic pathway or by $\mathrm{IXa} /$ VIIIa complex via intrinsic pathway.

It is also activated by Russell Viper venom (RVV). Factor Xa subsequently forms a macromolecular complex with its cofactors Va, a phospholipid surface and calcium ions to convert prothrombin into thrombin [3-5]. One muslim boy who presented with hemartrosis was diagnosed with severe deficiency of factor $\mathrm{X}$. Hemarthrosis becuase of severe factor $X$ deficiency is rare presentation [6] which compelled us to report .

\section{Case report}

A 2 year old muslim boy was brought in paediatric OPD for complaints of swelling in right knee.

On further evaluation history of similar illness was confirmed in the past. Clinical examination confirmed hemarthrosis.

Systemic examination did not reveal any other significant findings. A provisional diagnosis of Hemophilia A was made.

The child was refered to department of hematology for confirmation of factor VIII deficiency.

Routine hematological tests were done which were found within normal limits. Platelet count, bleeding time, coagulation time, Prothrombin Time ( PT ) and Activated Partial Prothrombin Time (APTT) were done .

First stage analysis confirmed disorder of common pathway as PT and APTT both were prolonged.

The mixing experiments, Russell viper venom test and factor deficient plasmas were used to confirm the specefic factor deficiency.

Factor X deficiency was diagnosed. Activity of factor X was found to be less than $1 \%$. The results are shown in Table no 1 and 2 . 


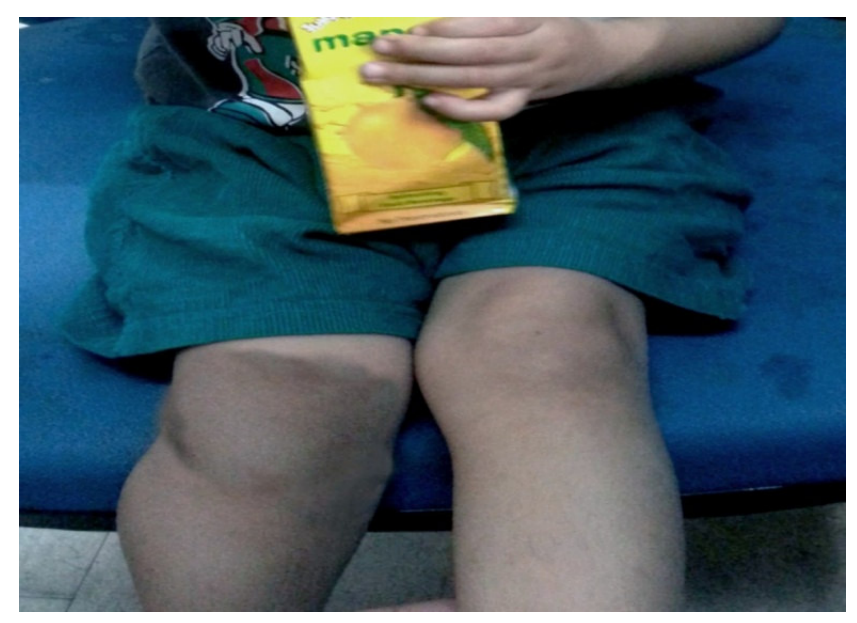

Fig 1: Hemarthosis in Right knee

Table 1: Results of hematological tests and coagulation profile

\begin{tabular}{|l|l|l|l|l|}
\hline S No. & Name of Test & Control/Ref. range & Test results & Interpretation \\
\hline 1. & Bleeding Time (Ivy method ) & 3 to 10 minutes & 6 minutes & \\
\hline 2. & Clotting time & 2 to 6 minutes & 15 minutes & prolonged \\
\hline 3. & Platelet count & 100000 to $300000 / \mathrm{cmm}$ & 2.20 lacs $/ \mathrm{cmm}$ & \\
\hline 4. & Prothrombin Time & 11 to 16 seconds & 80 seconds & prolonged \\
\hline 5 & Activated Partial Prothrombin Time & 32 to 40 seconds & 150 seconds & prolonged \\
\hline 6. & Russell' s viper venom test & 11 to 13 seconds & 50 seconds & prolonged \\
\hline 7. & Fibrinogen & 150 to $400 \mathrm{mg} \%$ & $250 \mathrm{mg} \%$ & \\
\hline
\end{tabular}

Table 2: Mixing experiments and assay

\begin{tabular}{|l|l|l|l|}
\hline S No & Mixing experiment done with & Result & Interpretation \\
\hline 1. & Adsorbed plasma & PT, APTT not corrected & Disorder of common pathway \\
\hline 2. & Fresh serum & PT, APTT corrected & Fibrinogen deficiency ruled out \\
\hline 3. & Normal plasma & PT, APTT corrected & Factor X deficiency \\
\hline 4. & Factor VIII deficient plasma & PT, APTT corrected & Factor VIII deficiency ruled out \\
\hline 5. & Factor IX deficient plasma & PT, APTT corrected & Factor IX deficiency ruled out \\
\hline 6. & Factor X deficient plasma & PT , APTT not corrected & Factor X deficiecy \\
\hline 7. & Factor X activity & Less than $1 \%$ & Factor X deficiency \\
\hline
\end{tabular}

\section{Discussion}

Factor X deficiciency is commonly an inherited disease however it has occasionally developed in patients with liver diseases, vitamin $\mathrm{K}$ deficiency, amyloidosis, multiple myeloma, mycoplasma pneumoniae infection, leprosy and methyl bromide exposure [6-8]. The gene for factor $\mathrm{X}$ is located on chromosome 13q32 .The inherited deficiency is transmitted in incomplete autosomal recessive pattern. Clinically significant bleeding usually do not appear if activity of factor $\mathrm{X}$ is more than $10 \%$. The homozygosity of transmission is usually seen in groups where consanguinity of marriages is common occurrence like musllims, jews. Severe deficiency of factor $\mathrm{X}$ has been seen in Pakistan where such marriages are common [9]. A variety of mutations result in defects involving either reduction in antigen or defect in one or more activation pathways [4]. Two types are described. Type-I, in which reduction in factor $\mathrm{X}$ activity parallels reduction in factor $\mathrm{X}$ antigen, 
and type-II in which activity is less than antigen [10]. The factor $\mathrm{X}$ is required to convert prothrombin into thrombin which subsequently converts fibrinogen into fibrin. Factor $\mathrm{X}$ deficiency presenting as hemarthrosis is seen rarely.

\section{Conclusion}

Hemarthrosis is an usual presentation in Hemophilia A and B. Factor $\mathrm{X}$ deficiency should also be made as provisional diagnosis when consanguinity of marriage and particular ethnic group is noted. Prolonged PT and APTT should always be investigated further by mixing experiments to confirm factor $\mathrm{X}$ deficiency. The patient had factor $\mathrm{X}$ deficiency of severe variety presenting as hemarthrosis who is either Prower kindred ( presence of antigen ) or Stuart kindred (absence or reduced antigen).

\section{Conflict of Interests}

We certify that there is no conflict of interests for publication of this paper.

\section{References}

1. Hilgartner MW MC Millan CW:Coagulation disorders. In Blood Diseases of Infancy and Childhood eds. Miller DR, Bachner RL, Mc Millan CW and Miller LP $5^{\text {th }}$ edn. The C.V.Mosby Company St. Louis P. 894 1984.

2. Hossouna HI:Laboratory Evaluation of Hemostatic Disorders, Hematology Oncology Clinic of North America-Coagulation disorder II/W.B.Saunders, Philedelphia. Pp 1242-1243,December 1993.

\section{Case Report}

3. Uprichard J, Perry DJ. Factor X deficiency. Blood Rev 2002; 16(2):97-110.

4. Hertzberg M. Biochemistry of factor X. Blood Rev 1994; 8(1):56-62.

5. Saligsohn U, White GC. Inherited deficiencies of coagulation factors II, V, VII, XI and XIII and the combined deficiencies of Factors V and VIII and of the Vitamin $\mathrm{K}$ dependent factors. In: Beutler E, Lichtman MA, Coller BS, Kipps TJ, Seligsohn U (editors) Williams Hematology $\left(6^{\text {th }}\right.$ edition, International Edition).McGraw-Hill Medical Publishing Division. New York 2001. P 1617-38.

6. Kouides PA, Kulzer L. Prophylactic treatment of severe factor $\mathrm{X}$ deficiency with prothrombin complex concentrate. Haemophilia 2001; 7(2):220-3.

7. Bajaj SP, Joist NH. New insights into how blood clots: implications for the use of APTT and PT as coagulation screening tests and in monitoring of anticoagulant therapy. Semin Thromb Hemost 1999; 25(4):407-18.

8. Dalal A, Pradhan M , Agarwal S. Genetics of Bleeding Disorders . Int J Hum Genet 2006; 6(1): 27-32.

9. Anwar M, Hamdani SN, Ayyub M, Ali W. Factor $\mathrm{X}$ deficiency in North Pakistan . J Ayub Med Coll Abbottabad 2004; 16 (3):1-4.

10. Peyvandi F, Menegatti M, Santagostino E, Akhavan S, Uprichard J, Perry DJ, et al. Gene mutations and three-dimensional structural analyses in 13 families with severe factor $\mathrm{X}$ deficiency. $\mathrm{Br} \mathrm{J}$ Haematol 2002; 117(3):685-92.

\section{How to cite this article?}

Sinha S, Barik S. Factor X Deficiency: A Rare Case of Inherited Coagulation Disorder Presenting As Hemarthrosis. Int J Med Res Rev 2014;2(3):253- 255. doi:10.17511/ijmrr. 2014.i03.14. 